\title{
Špindlerưv Mlýn patřil popáté plicní cirkulaci
}

Již páté symposium Pracovní skupiny plicní cirkulace České kardiologické společnosti se ve dnech 14. až 15. ledna 2011 konalo ve Špindlerově Mlýně, a zdá se tedy, že se tak zrodila nová tradice. Zdařilé setkání, které bylo letos pořádáno ve spolupráci s Českou společností pro trombózu a hemostázu a jehož se zúčastnilo více než 150 účastníků nejen z Čech, ale i ze Slovenska, se věnovalo aktualitám $\mathrm{v}$ problematice plicní cirkulace $\mathrm{v}$ uplynulém roce, zobrazovacím metodám $\mathrm{v}$ diagnostice onemocnění plicní cirkulace, funkčnímu vyšetřování u onemocnění plicní cirkulace, tromboembolické nemoci, plicní hypertenzi u srdečního selhání a konečně diagnostice a léčbě pacientů s plicní arteriální hypertenzí sdruženou s vrozenými srdečními vadami. Dvoudenní jednání, jehož odbornými garanty byli prof. MUDr. M. Aschermann, DrSc., místopředseda České kardiologické společnosti (ČKS) a předseda Pracovní skupiny plicní cirkulace ČKS, MUDr. P. Jansa, vedoucí Centra pro plicní hypertenzi II. interní kliniky kardiologie a angiologie VFN v Praze a 1 . LF UK, a prof. MUDr. J. Kvasnička (rovněž z 1. LF UK a VFN Praha), předseda České společnosti pro trombózu a hemostázu ČLS JEP, dokumentovalo, že tato interdisciplinární problematika se v posledních letech stala vedle klasických velkých témat kardiologie, pneumologie a intenzivní péče nepřehlédnutelnou, a to nejen díky pokroku v poznání patofyziologie poruch plicní cirkulace, ale především díky významnému vývoji v její farmakoterapii.

\section{Aktuality v plicní hypertenzi 2010}

M. Aschermann zahájil dvoudenní jednání rekapitulací novinek $\mathrm{v}$ diagnostice a léčbě poruch plicní cirkulace z roku 2010; soustředil se zejména na nové doporučené postupy týkající se plicní hypertenze, novinky v diagnostice a hodnocení závažnosti plicní arteriální hypertenze a perspektivní léčivé př́ípravky a konečně i na genetiku a genomiku plicní arteriální hypertenze.

Za zmínku stojí, že v současné době se rozlišují nemocní s plicní hypertenzí s nízkým a vysokým rizikem, přičemž kritérii jsou příznaky pravostranného srdečního selhání, progrese symptomů, funkční klasifikace NYHA/WHO, výsledky testu šestiminutovou chůzí, echokardiografický nález, hemodynamické parametry a nově i koncentrace natriuretických peptidů.

$\mathrm{V}$ diagnostice a hodnocení závažnosti zůstávají nadále zlatým standardem echokardiografie a pravostranná katetrizace, stále více však ke zdokonalení diagnostiky přispívá magnetická rezonance, a rychle roste význam natriuretických peptidů. Zjistí-li se jejich zvýšené hodnoty u mladých, lehce symptomatických, ale jinak zdravých jedinců, je to indikace $\mathrm{k}$ jejich zařazení do dispenzarizace, aby bylo možno případnou plicní hypertenzi zachytit co nejdříve a v co nejčasnějším stadiu. Z hlediska hodnocení závažnosti a prognózy zůstávají nejlepšími parametry hemodynamiky střední tlak v pravé síni, střední tlak v plicnici a srdeční index, v echokardiografii TAPSE (systolický pohyb trikuspidálního anulu), tolerance zátěže podle výsledku šestiminutového testu chůze, funkční klasifikace dle NYHA/WHO (průměrné přežívání ve funkční třídě I-II šest let, ve třídě III 2,5 roku a ve třídě IV pouhých šest měsíců) a natriuretické peptidy (nezávislý prediktor prognózy - koreluje s šestiminutovým testem chůze, srdečním indexem, plicní vaskulární rezistencí i středním tlakem $\mathrm{v}$ pravé síni, ale nikoli se středním tlakem v plicnici - i marker reakce na léčbu).

Je zajímavé, že dosud nebylo standardizováno dlouhodobé sledování pacientů s plicní hypertenzí, a volí se tedy jedna ze dvou možných strategií - klinická, vycházející jen z funkční klasifikace, bez stanovení prospektivního cíle, s intervaly sledování tř̌i až šest měsíců), nebo cílená, s určením hodnoty některého cílového parametru a stanovením intervalu kontrol; pokud se cíle nedosáhne, eskaluje se léčba $\mathrm{z}$ monoterapie až na trojkombinaci. Ukazuje se, že pomocí druhého přistupu se daří dosahovat lepšího přežívání. Možná je též kombinace obou.

Pokud jde o genetiku plicní arteriální hypertenze, bylo dosud identifikováno 298 mutací genu pro BMPR2 (bone morphogenetic protein receptor - type 2) - tyto mutace byly zjištěny zhruba u $20 \%$ nemocných s idiopatickou $\mathrm{PAH}$ a předpokládá se jejich souvislost s proliferací hladkých svalových buněk plicních tepen. Ze zjištění, že anomálie genu pro BMPR2 existují i u sekundárních forem $\mathrm{PAH}$, vyplývá možnost, že je to právě genetický základ, který hraje predispoziční roli u PAH spojené s vrozenými srdečními vadami. Odtud také vznikla hypotéza, že podobně jako u ostatních forem $\mathrm{PAH}$ může prítomnost genetické predispozice u některých pacientů s vrozenými srdečními vadami vysvětlit rychlejší či pomalejší progresi lézí plicních tepen u různých pacientů. Genetické studie zaměřené na definování subtilních genetických mutací budou tedy mít do budoucna velký význam nejen u hereditární a idiopatické plicní arteriální hypertenze, ale i u jejích dalších forem.

Cílem léčby plicní arteriální hypertenze u nemocných ve funkční třídě I-II je stabilizace (nezhoršení) stavu, u pacientů v třídě III-IV jeho zlepšení. Farmakoterapie vychází ze stále hlubších znalostí patofyziologie a je zaměřena na procesy vasokonstrikce, proliferace, zánětu a trombózy, a to v adventicii, medii, endotelu i krvi. V terapeutické paletě vedle konvenční léčby (léčba srdečního selhání, antagonisté kalciových kanálů, antikoagulancia) stále více převažuje léčba specifická:

> antagonisté endotelinových receptorů - bosentan (Tracleer), ambrisentan (Volibris);

> inhibitory fosfodiesterázy 5 (PDE-5) - sildenafil (Revatio), tadalafil (Adcirca);

> prostanoidy - perorální beraprost, inhalační iloprost (Ventavis), intravenózní epoprostenol (Flolan), subkutánní treprostinil (Remodulin).

Kromě monoterapie se stále více uplatňuje kombinační léčba, a to hned od začátku léčby, nebo jako sekvenční.

Perspektivou jsou některé v současnosti vyvíjené, zkoušené nebo experimentální léky:

> inhibitory tyrosinkinázy (sorafenib) a destičkového růstového faktoru (imatinib),

> vasoaktivní intestinální peptid (aviptadil),

> agonisté intracelulárních receptorů pro prostacyklin (selexipag),

> tkáňově specifický antagonista receptorů pro endotelin (macitentan),

> prímý stimulátor solubilní guanylátcyklázy (riociguat),

> inhibitor Rho-kinázy (fasudil),

, inhibitor zpětného vychytáváni serotoninu (fluoxetin). 
Přibývá též snah o ovlivnění angiogeneze, využití endotelových progenitorových buněk, které by zlepšily kapilární plicní řečiště, jakož i kmenových buněk využitelných $\mathrm{v}$ antiremodelační strategii nebo při navození reverzní remodelace. Nové léky užívané v terapii PAH jsou totiž charakterizovány nejen vasodilatačními účinky, ale také působením na progresi remodelačních změn. Perspektivním cílem farmakoterapie je však nejen zpomalit remodelaci, ale dokonce ji zvrátit a indukovat deremodelaci.

To vše by dále mělo zlepšit osud pacientů s plicní hypertenzí, a pomoci tak navázat na pozitivní vývoj v uplynulém desetiletí, kdy se významně zlepšilo jejich přeživání; nejvíce u idiopatické plicní arteriální hypertenze, dále u PAH při infekci HIV, onemocněních pojiva a také při vrozených srdečních vadách.

\section{Nová americká, evropská i česká doporučení}

Nová doporučení pro diagnostiku a léčbu plicní hypertenze vydaly jako první americké odborné společnosti (ACCF/AHA, červen 2009), Evropská kardiologická společnost je však následovala vzápětí (červen 2009); inovovaná česká doporučení byla dokončena v prosinci 2010 a jsou publikována v tomto čísle časopisu Cor et Vasa. Podrobněji je představil MUDr. P. Jansa.

Plicní arteriální hypertenze (PAH) je charakterizována jako primární, potenciálně fatální onemocnění plicních arteriol, které vede $\mathrm{k}$ progredující prekapilární plicní hypertenzi a bez léčby relativně rychle k selhání pravé srdeční komory a k úmrtí nemocného. Vzniká bud' z neznámé př́činy (idiopatická PAH), v souvislosti s mutací některých genů (hereditární $\mathrm{PAH}$ ), případně $\mathrm{v}$ souvislosti s expozicí některým farmakům a toxickým látkám, nebo je asociována se známou vyvolávající příčinou (systémová onemocnění pojiva, HIV infekce, portální hypertenze, vrozené srdeční vady s levopravým zkratem, schistosomiáza, chronické hemolytické anemie - asociovaná $\mathrm{PAH})$. Hemodynamicky je PAH definována středním tlakem v plicnici $>25 \mathrm{~mm} \mathrm{Hg}$ a normálním tlakem v zaklínění. Pro normotenzi svědčí hodnoty $8-21 \mathrm{~mm} \mathrm{Hg}$, hodnoty v šedé zóně 22-24 mm Hg se považují za hraniční tlaky.

Hlavní změny v oblasti plicní mikrocirkulace u pacientů s PAH zahrnují vasokonstrikci, cévní remodelaci (proliferují buňky endotelu, hladkého svalstva a dochází ke změnám $\mathrm{v}$ extracelulární matrix) a trombózu $\mathrm{v}$ důsledku relativní nadprodukce faktorů s účinky vasokonstrikčními, růstovými a trombogenními (endotelin, serotonin, tromboxan) nad faktory s účinky vasodilatačními, antiproliferačními a antitrombotickými (NO, prostacyklin, vasoaktivní intestinální peptid).

Současná klinická klasifikace, která v roce 2008 nahradila dřívější tzv. Benátskou klasifikaci, rozeznává pět základních skupin chronické plicní hypertenze:

> První skupinu představuje plicní arteriální hypertenze $(\mathrm{PAH})$, perzistující plicní hypertenze novorozenců, plicní venookluzivní nemoc a plicní kapilární hemangiomatóza.

> Druhá skupina je označována jako plicní hypertenze při srdečních onemocněních.

> Třetí skupina zahrnuje plicní hypertenzi při plicních onemocněních anebo hypoxii.

> Čtvrtá skupina je označována jako chronická tromboembolická plicní hypertenze (CTEPH).

> Pátá skupina zahrnuje chronické plicní hypertenze z jiných nebo nejasných přičin (při některých hematologických, systémových a metabolických chorobách a dále při vrozených srdečních vadách jiných než s levopravým zkratem).

O způsobu léčby rozhoduje test akutní plicní vasodilatace. Pouze nemocní s pozitivním testem jsou indikováni $\mathrm{k}$ léčbě vysokými dávkami blokátorů kalciových kanálů - konvenční léčbě, k níž dále patří léčba srdečního selhání a léčba antikoagulační.
V případě negativního testu je vedle chronické antikoagulační léčby indikována specifická farmakoterapie (viz výše), a to jako monoterapie, nebo jako kombinační léčba. Byl to právě intenzivní rozvoj specifické farmakoterapie v posledních 20 letech, který přispěl k rozvoji zájmu o plicní arteriální hypertenzi jako o onemocnění dřive prakticky neléčitelné, avšak dnes relativně dobře terapeuticky ovlivnitelné.

\section{Zásadní je časná diagnostika a co nejdřive zahájená léčba}

Stále více se ukazuje, že klíčovým faktorem osudu nemocného je co nejčasnější záchyt, stanovení diagnózy, prognostická stratifikace a zahájení intenzivní léčby (včetně kombinované) v co nejčasnějším stadiu (nejnižší funkční třídě) - v průběhu symposia o tom hovořil např. prof. A. Linhart. Nepoznaná a neléčená plicní arteriální hypertenze má totiž velmi rychlou progresi a nepř́znivou prognózu, naopak včasná léčba jednoznačně zlepšuje nejen kvalitu života, ale také přežívání, a zabraňuje ireverzibilním změnám, jak přesvědčivě ukázala studie EARLY s bosentanem, jediná studie s PAH ve funkční třídě II. Dostupnost stále širší škály diagnostických metod umožňuje zavádět systematický screening u definovaných skupin populace, zejména u pacientů se systémovým onemocněním pojiva, ale i u HIV pozitivních nemocných, s rodinnou anamnézou plicní arteriální hypertenze, s jaterním onemocněním, a tím lze dosáhnout významného zkrácení doby do diagnózy, která je - jak se ukazuje - kritická pro další osud pacienta. Dává to rovněž větší možnosti stagingu onemocnění a výše rizika, $\mathrm{z}$ něhož pak vycházejí rozdílné prrístupy $\mathrm{k}$ léčbě (méně či více agresivní, snaha o zachování stavu či jeho zlepšení atd.). Stále více také platí, že léčba plicní arteriální hypertenze patři do zkušených specializovaných multidisciplinárních center, schopných zajištovat na nejvyšší úrovni a v nejvyšší kvalitě diagnostiku, medikamentózní a eventuálně i chirurgickou léčbu i dlouhodobé sledování nemocných. Právě díky tomuto př́stupu se $\mathrm{v}$ posledním desetiletí podařilo zásadním způsobem zlepšit jak kvalitu, tak do jisté míry i délku života nemocných především s idiopatickou plicní arteriální hypertenzí.

\section{Plicní arteriální hypertenze a vrozené srdeční vady}

Podobně jako u idiopatické PAH došlo v posledních letech $\mathrm{k}$ zásadnímu pokroku i v oblasti plicní hypertenze různých etiologií, mj. plicní arteriální hypertenze související se systémovou sklerodermií, chorobami pojiva, infekcí HIV a také s vrozenými srdečními vadami, především vadami Eisenmengerova typu (se zkratem mezi systémovým a plicním oběhem).

Právě posledně jmenované formě plicní hypertenze proto bylo také věnováno jedno ze symposií jednání ve Špindlerově Mlýně. Sponzorovala je společnost Actelion a jeho protagonisté prof. Iveta Šimková (Kardiologická klinika NÚSCH Bratislava), MUDr. Petra Antonová (Kardiocentrum dospělých a Interní klinika FN Motol a 2. LF UK v Praze) a MUDr. Tomáš Zatočil (Ambulance vrozených srdečních vad $\mathrm{v}$ dospělosti Interní kardiologické kliniky FN Brno-Bohunice) - v jeho programu jednak představili stále se zlepšující výsledky specifické léčby těchto pacientů v posledních letech na svých pracovištích, jednak podali přehled epidemiologie a patofyziologie i možností diagnostiky a léčby těchto nemocných.

Vrozené srdeční vady v dospělosti jsou v posledních letech velmi aktuálním tématem. Významné pokroky dětské kardiologie a kardiochirurgie $\mathrm{v}$ průběhu několika posledních desetiletí vedly ke zcela dramatickému vzestupu počtu pacientů narozených $\mathrm{s}$ vrozenými srdečními vadami, kteří se dožívají dospělého věku (místo někdejších 10 až $20 \%$ je to dnes 80 až 90 \%). Navzdory setrvalé incidenci vrozených srdečních vad tak počet těch, kdo s nimi dlouhodobě žijí, trvale narůstá. 
Rychlé a zásadní proměny epidemiologie vrozených srdečních vad a demografického profilu pacientů kladou vyšší požadavky na výzkum problematiky vrozených srdečních vad nejen u dětí, ale i v dospělosti, včetně jejich komplikací, jako je plicní arteriální hypertenze. Ta je asociována přibližně s 5-10 \% vad, jejich prevalence se tedy odhaduje na $2-13 /$ milion obyvatel, přičemž 24-50\% tvoří vady Eisenmengerova typu. Jde o specifickou populaci, jež též vyžaduje specifickou péči a kterou je třeba chránit před celou řadou specifických rizik (včetně rizika nerovnováhy mezi sklonem ke krvácení a sklonem k trombóze), přičemž mnohé znalosti managementu i standardů zatím chybějí. V současnosti jsou základním vodítkem doporučení Evropské kardiologické společnosti z roku 2008.

Dnes platná doporučení klasifikují tyto poruchy do čtyř podskupin:

> Nejmenší je skupina plicní arteriální hypertenze po korekci vrozené srdeční vady, kde se většinou volí konzervativní př́stup.

> Druhou skupinou je plicní arteriální hypertenze při malých septálních defektech, kdy jde většinou o koincidenci dvou klinických jednotek nebo o anomální reakci plicního řečiště na jiné, napr. genetické podněty; i zde postačuje konzervativní př́stup.

> Do třetí skupiny patří plicní arteriální hypertenze asociovaná se středně velkým nebo velkým defektem, ale se systémovo-plicním (levopravým) zkratem; zde je v některých př́padech možná chirurgická léčba, v kombinaci s konzervativní.

> Konečně vrcholem pyramidy a nejzávažnější formou je plicní arteriální hypertenze sdružená s vadami Eisenmengerova typu; na systémové úrovni ireverzibilní. Velký význam zde má typ a velikost zkratu, jeho směr a hemodynamické parametry komunikace.

Při levopravém zkratu se plicní arteriální hypertenze rozvíjí $\mathrm{v}$ důsledku zvýšeného průtoku krve a smykového stresu v plicním tepenném řečišti; jakmile plicní arteriální tlak př̀evýší systémový tepenný tlak, mění se levopravý zkrat na pravolevý a vzniká tzv. Eisenmengerův syndrom. $Z$ vrozených srdečních vad $k$ němu mohou vést jak jednoduché defekty (defekt mezisíňového septa, defekt mezikomorového septa, ductus arteriosus patens), tak i složitější defekty (atrioventrikulární septální defekt, truncus arteriosus, aortopulmonální okénko, komplexní pulmonální atrezie a jednokomorové srdce), a dokonce i chirurgicky vytvořené aortopulmonální spojky (Pottsovy a Watersonovy shunty). Pravděpodobnost vzniku a vývoje PAH závisí na velikosti a lokalizaci intrakardiálního nebo extrakardiálního defektu, na načasování a úspěšnosti provedené chirurgické korekce a pravděpodobně i na genetických determinantách.

Platí, že „není zkrat jako zkrat“, tedy že ne každý zkrat nutně vede $\mathrm{k}$ plicní arteriální hypertenzi. Klíčová je velikost zkratu, respektive defektu, jeho umístění a tlakový spád - to vše rozhoduje o objemovém a tlakovém přetížení. Existují též interindividuální rozdíly (př̀i stejně velkém defektu se může u jednoho nemocného plicní arteriální hypertenze vyvinout, u jiného nikoli). Proto je tak dominantním vyšetřením echokardiografie, která dovoluje zhodnotit nejen velikost defektu, ale i jeho anatomickou a hemodynamickou závažnost.

Plicní arteriální hypertenze a Eisenmengerův syndrom mohou být de facto způsobovány jak jednoduchými, tak velmi komplexními (cca $30 \%$ př́padů) vrozenými srdečními vadami. Plicní arteriální hypertenze se vyvijí u pacientů s defekty většího rozměru při truncus arteriosus prakticky ve všech př́padech, při defektu mezikomorového septa v $50 \%$ a při defektu mezisíňového septa v $10 \%$ př́padů. Mezi nemocnými s defekty síňového septa je vyšší incidence PAH u osob s defekty sinus venosus (16\%) než u osob s defekty ostium secundum (4\%). Vývoj plicní hypertenze závisí rovněž na velikosti defektu. Při malém až středně velkém defektu komorového septa se PAH vyvine pouze u $3 \%$ pacientů, naopak při větších defektech (průměr $>1,5 \mathrm{~cm}$ ) je postiženo až $50 \%$ nemocných. U některých pacientů se závažnou plicní arteriální hypertenzí se daří detekovat až po „úspěšné“ chirurgické korekci srdeční vady. $\mathrm{V}$ řadě těchto prŕpadů není jasné, zda byly ireverzibilní léze plicních tepen prrítomny již před chirurgickou intervencí, anebo zda došlo $\mathrm{k}$ jejich progresi navzdory úspěšné korekci vady.

Eisenmengerův syndrom neznamená jen cyanotickou zkratovou vadu a plicní arteriální hypertenzi - je to multisystémová vada vyžadující interdisciplinární př́stup. Levopravý zkrat postupně vede ke zvýšení průtoku krve plicním řečištěm a zvýšené cévní rezistenci, tedy $\mathrm{k}$ objemovému a tlakovému přetížení. Nakonec se zkrat mění na pravolevý a porucha se projeví v důsledku př́tomnosti neokysličené krve v systémovém řečišti cyanózou, dušností, polycytemií, arytmiemi, synkopami, cefaleou, bolestmi na hrudi až srdečním selháním. To mủže být zhruba až u čtvrtiny pacientů príćinou úmrtí. Plicní hypertenze vyvolává rovněž tvorbu trombů $\mathrm{v}$ plicnici a arytmie, hypoxie vede ke stimulaci kostní dřeně a relativní sideropenii v důsledku velkého metabolismu železa, časté jsou hemoptýza a také cévní mozkové př́hody (důsledek hypoxie nebo poruch mikrocirkulace). Hypoxie periferních orgánů vede $\mathrm{k}$ jaterní dysfunkci a větší náchylnosti k infekcím (bronchopneumonie, endokarditidy, mozkové abscesy) a konečně zvýšený metabolismus v kostní dřeni zvyšuje koncentraci kyseliny močové (osteopatie).

$\mathrm{Na}$ druhé straně je prognóza lepší než u idiopatické plicní hypertenze a jiných druhů plicní arteriální hypertenze se srovnatelnou hemodynamikou, a to vzhledem $\mathrm{k}$ dlouhodobému zachování funkce pravé komory díky přetrvávání jejího fetálního fenotypu po narození. Nicméně stále platí, že ve srovnání s ostatními vrozenými srdečními vadami je $\mathrm{v}$ těchto případech přežívání kratší, a to až o dvě desetiletí (Eisenmengerův syndrom má nejhorší funkční postižení ze všech vrozených srdečních vad).

Možnosti léčby byly historicky velmi omezené (jen paliace a preventivní či režimová opatření nebo transplantace srdce a plic, obtížně dosažitelná a s nejistým výsledkem) a málo uspokojivé. Při konvenční léčbě bylo nutno pacienta vyšetřovat minimálně jednou ročně, doporučovalo se vyhýbat se dehydrataci a nadměrné fyzické zátěži a zakazovalo těhotenství (mortalita > $40 \%$ ); důležitá byla léčba arytmií, zvláště s ohledem na hemodynamiku těchto nemocných, opatrnosti bylo třeba při podávání diuretik (snižují srdeční výdej a průtok plícemi, čímž zvyšují riziko trombózy). Kontroverzní zůstávala antikoagulace - nutností je snaha o rovnováhu mezi tendencí ke krvácení/trombózám. Nedoporučuje se rutinní provádění venepunkcí a venesekcí, nebot dochází k rozvoji deficitu železa a změně charakteru erytrocytů (riziko cévních mozkových př́hod). Oxygenoterapie nepomáhá, ale ani neškodí, takže ji lze považovat za jakousi psychoterapeutickou podporu.

\section{Specifická léčba plicní arteriální hypertenze u pacientů s vrozenými srdečními vadami}

Skutečně účinná léčba by měla vždy ovlivňovat jak endotelovou dysfunkci, tak obstrukční remodelaci plicních arterií. Proto objev a zavedení nových terapeutických modalit tzv. specifické léčby u idiopatické plicní arteriální hypertenze otevřely nové možnosti i pro léčbu PAH u pacientů $s$ vrozenými srdečními vadami Eisenmengerova typu a se setrvalou pooperační PAH. Nové léky účinkují prostřednictvím patofyziologických mechanismů. U Eisenmengerova syndromu vede genetický substrát $\mathrm{v}$ kombinaci se zvýšeným smykovým stresem k nerovnováze mezi vasokonstriktory a vasodilatátory - a právě na tom je také postavena specifická léčba, která zásadně změnila paradigma péče o tyto nemocné. Specifická léčba se dnes opírá o tř́i základní skupiny léčiv: 
> prostanoidy (jsou však spojeny s určitými riziky - např. při intravenózní léčbě epoprostenolem je zvýšeno riziko infekcí, infekční endokarditidy a paradoxní embolizace);

> inhibitory fosfodiesterázy 5 (PDE-5) - ovlivňují hladkou svalovinu cév, snižují závažnost $\mathrm{PAH}$, a tím i funkční třídu dle WHO, mají prímé účinky na hemodynamiku a saturaci, jsou velmi dobře tolerovány, a užívají se proto jako léčba 2 . linie v sekvenční nebo také v kombinované léčbě;

> antagonisté endotelinových receptorů - velmi dobře účinné a tolerované, prrípravky podávané per os; zatím nejvíce dat existuje pro duálního antagonistu endotelinových receptorů bosentan (studie BREATHE-5, a nověji studie Dimopoulose a spol., obě publikované v časopise Circulation - viz dále).

\section{Studie BREATHE-5}

I když dlouhodobé podávání vasodilatačních látek (prostacyklinů, inhibitorů fosfodiesterázy a zejména antagonistů endotelinových receptorů) prokazatelně zlepšuje funkční kapacitu, toleranci zátěže a plicní hemodynamiku u nemocných s idiopatickou PAH, dlouhodobý účinek této léčby u nemocných s plicní arteriální hypertenzí v souvislosti s vrozenými srdečními vadami zůstával dlouho neznámý. Provedené dvojitě zaslepené studie s novými vasodilatačními látkami, včetně analogů prostacyklinů (subkutánní treprostinil, inhalační iloprost, perorální beraprost) a inhibitorů fosfodiesteráz (sildenafil) zahrnovaly pouze malé soubory nemocných s vrozenými srdečními vadami. A tak první rozsáhlejší randomizovanou, dvojitě zaslepenou, placebem kontrolovanou studií, hodnotící rozsáhlejší kohortu nemocných s Eisenmengerovým syndromem a plicní arteriální hypertenzí ve funkční tř́dě III dle WHO, byla studie s duálním antagonistou endotelinových receptorů bosentanem (Tracleer). Šlo o studii BREATHE-5 (Bosentan Randomized trial of Endothelin Antagonist THErapy for pulmonary hypertension-5). Byla to první studie uspořádaná jako multicentrická, randomizovaná (2:1), dvojitě zaslepená a kontrolovaná placebem, jejímž úkolem bylo zhodnotit účinky bosentanu na systémovou saturaci kyslíkem, plicní a systémovou hemodynamiku a zátěžovou kapacitu u pacientů starších než 12 let, s Eisenmengerovým syndromem a plicní arteriální hypertenzí ve funkční třídě III dle WHO, která měla zhodnotit potenciální přednosti této terapeutické modality ve vztahu $\mathrm{k}$ dlouhodobému osudu nemocných.

Do studie bylo v patnácti centrech Evropy, Severní Ameriky a Austrálie zařazeno 54 pacientů a randomizováno do skupiny léčené bosentanem $(n=37)$ nebo placebem $(n=17)$, a to po dobu šestnácti týdnů. Výsledky publikované v časopise Circulation (Galiè $\mathrm{N}$, Beghetti M, Gatzoulis MA, et al. Bosentan therapy in patients with Eisenmenger syndrome: a multicenter, double-blind, randomized, placebo-controlled study. Circulation. 2006;114:48-54) prokázaly u této skupiny pacientů jednoznačný terapeutický prínos. Terapie bosentanem (první čtyři týdny $62,5 \mathrm{mg}$ dvakrát denně, dalších dvanáct týdnů $125 \mathrm{mg}$ dvakrát denně) zlepšila toleranci fyzické zátěže (vzdálenost při šestiminutovém testu chůze se prodloužila v průměru o 53,1 metru $[p=0,008]$ ) a hemodynamiku (průměrný pokles indexu plicní vaskulární rezistence - PVRI činil $472 \mathrm{dyn} \cdot \mathrm{s} / \mathrm{cm}^{5}[p=0,04]$, a to beze změny periferní saturace kyslíkem a při velmi dobré toleranci léčby). Prokazatelně poklesl podíl pacientů, u nichž došlo ke klinickému zhoršení.

Jsou to zjištění o to významnější, že poruchy s Eisenmengerovou fyziologií jsou nejpokročilejší formou plicní arteriální hypertenze vyskytující se v souvislosti s vrozenými srdečními chorobami. U těchto nemocných je ve srovnání s pacienty s jinými formami vrozených srdečních vad mimořádně výrazně zhoršena zátěžová kapacita, dochází i k orgánovému poškození a zvyšuje se riziko předčasného úmrtí. Podávání bosentanu vede u těchto velmi těžkých a obtížně léčitelných pacientů k rychlému zlepšení jak zátěžové kapacity, tak funkční třídy podle WHO, tedy ke zlepšení funkční kapacity plic i plicní cévní rezistence.

$\mathrm{Na}$ základě toho se bosentan stal v současnosti v Evropě jediným schváleným přípravkem pro léčbu PAH související $s$ vrozenými srdečními vadami. Studie BREATHE-5 zcela pozměnila nejen představu, že jde o stabilní nemocné, ale i tu, že nejsou prŕístupní léčbě. To je mimořádně důležité vzhledem $\mathrm{k}$ faktu, že díky úspěšnosti medicíny pacientů s tímto typem vad, kteři přežívají do dospělosti, rychle přibývá.

\section{Nejen zlepšení funkčního stavu, ale i prodloužené přežívání}

Zlepšení stavu a sledovaných parametrů bylo pozorováno i v prodloužení studie BREATHE-5 na dobu 40 týdnů (studie BREATHE-OL, kde byl zachován účinek u aktivně léčených a došlo ke zlepšení u těch, kteří původně dostávali placebo), nicméně stále zůstávala otevřená otázka, zda u těchto pacientů lze rovněž oddálit nebo zvrátit plicní hypertenzi, tedy zda je možné zlepšit přežívání těchto pacientů.

Na tuto otázku měla odpovědět dlouhodobá studie provedená ve dvou největších centrech, sledujících nejvíce pacientů tohoto typu, v Londýně (Adult Congenital Heart Centre for Pulmonary Hypertension, Royal Brompton Hospital a National Heart and Lung Institute, Imperial College School of Medicine). Šlo o studii retrospektivní; vzhledem k tomu, že pozitivní vliv specifické terapie bosentanem u pacientů s Eisenmengerovým syndromem na hemodynamiku v malém oběhu, toleranci zátěže a funkční tř́du je nyní již jasně doložen, by bylo řazení pacientů do skupiny léčené placebem v prospektivní studii neetické. Byly proto shromážděny údaje ode všech pacientů sledovaných v těchto centrech během uplynulých deseti let a srovnáno přeživání při specifické léčbě a bez ní (celkem 229 pacientů ve věku 34,5 $\pm 12,6$ roku, $\mathrm{z}$ toho 74,6 \% žen). Většina $\mathrm{z}$ nich měla komplexní anatomické vady, 53,7 \% z nich bylo při vstupu do studie ve funkční třídě NYHA III nebo IV. Průměrné hodnoty klidové saturace byly 84,3\%, specifickou terapií bylo léčeno nebo tuto léčbu zahájilo v době sledování 68 nemocných $(29,7 \%)$.

Během sledování ( $v$ průměru čtyřletého) zemřelo celkem 52 nemocných, $\mathrm{z}$ nichž však pouze dva byli ze skupiny léčené specifickou terapií. Riziko úmrtí bylo u léčených nižší jak neadjustovaně, tak adjustovaně vzhledem $\mathrm{k}$ dalším rozdílným charakteristikám.

Výsledky této retrospektivní studie (Dimopoulos K. et al. Improved survival among patients with Eisenmenger syndrome receiving advanced therapy for pulmonary arterial hypertension. Circulation 2010;121:20-25) tedy přesvědčivě ukázaly, že specifická terapie bosentanem je u nemocných s Eisenmengerovým syndromem a plicní arteriální hypertenzí, kteří byli dříve považováni za „předem ztracené“ a bez možnosti účinné léčby, asociována s nižším rizikem úmrtí; kromě zlepšení hemodynamických parametrů a funkční třídy léčených je tedy při rozhodování o specifické terapii nutno brát v úvahu i zlepšení prognózy přeživání.

Celé symposium tedy vyznělo v závěr, že plicní arteriální hypertenze při vrozených srdečních vadách je preventabilní komplikací, že včasná diagnostika a včasná korekce umožňuje zamezit i vzniku Eisenmengerova syndromu, a že komplexní management, př́padné posouzení operability vrozené srdeční vady a včasné zahájení dnes dostupné specifické léčby plicní arteriální hypertenze, při níž jde hlavně o zkvalitnění života a zlepšení prognózy, je možný pouze ve specializovaných centrech (jedno centrum na milion obyvatel) s dostatečnými znalostmi, zkušenostmi a možnostmi. Jen v takových centrech lze těmto pacientům přidávat jak léta životu, tak život létům.

\section{Mgr. Jaroslav Hořejší, e-mail:jaroslav@hore.cz}

